\title{
Air Sickness
}

National Cancer Institute

\section{Source}

National Cancer Institute. Air Sickness. NCI Thesaurus. Code C34364.

A sensation of discomfort associated with air travel that may include nausea, vomiting, dizziness, or sweating. 